\title{
Relocating the Functions of Chineseness in Chinese Popular Music after the China Wind
}

\section{Chen-yu Lin}

\section{(2) OpenEdition}

\section{Journals}

Electronic version

URL: https://journals.openedition.org/chinaperspectives/10068

DOI: 10.4000/chinaperspectives. 10068

ISSN: 1996-4617

\section{Publisher}

Centre d'étude français sur la Chine contemporaine

Printed version

Date of publication: 1 June 2020

Number of pages: 7-14

ISSN: 2070-3449

\section{Electronic reference}

Chen-yu Lin, "Relocating the Functions of Chineseness in Chinese Popular Music after the China Wind", China Perspectives [Online], 2020-2 | 2020, Online since 01 June 2021, connection on 06 July 2021. URL: http://journals.openedition.org/chinaperspectives/10068; DOI: https://doi.org/10.4000/ chinaperspectives. 10068 


\title{
Relocating the Functions of \\ Chineseness in Chinese Popular Music after the China Wind
}

\author{
CHEN-YU LIN
}

\begin{abstract}
While the popularity of China Wind (zhongguofeng 中國風) music during the 2000s has waned somewhat since its peak, the notion of Chineseness in popular music requires reconfiguration. In the world of popular music, transnational flows of culture, migration, and capital have created various forms of Chineseness with different functions. This article examines two ways in which the perception of Chineseness functions in the music industry, namely as a re-centred Chineseness in the creative industries, and Chineseness as a globalising project, by examining the internationally franchised televised music contest The Voice of China and the recent work of two artists known for their China Wind songs, Jay Chou and Wang Leehom. Through textual analysis of media content and songs, as well interviews with industry practitioners, this article argues that Chineseness in today's Chinese popular music is often shaped by markets, industrial practices, media censorship, state policy, and cross-industry convergence, and musicians' artistry increasingly plays a part in forming and authorising the representation of Chineseness in contemporary Chinese popular music.
\end{abstract}

KEYWORDS: Chinese popular music, Chineseness, Jay Chou, Wang Leehom, China Wind music.

n the 2000s, China Wind (zhongguofeng 中國風) was blowing in Mandarin popular music (Mandopop). Fusing itself with music genres such as R\&B, rock, hip-hop, and pop ballads, China Wind songs developed a specific sound by employing traditional Chinese instruments in their orchestration while their lyrical content often involved laudatory references to Chinese traditional cultural artefacts and achievements. These China Wind pop songs also articulate a "parcel" of what Chinese are supposed to learn (Chow and De Kloet 2011) while constructing a decontextualised and then re-contextualised "collage" of ancient China (Chung 2011). Taiwan's music industry is often recognised as the centre of this trend as it fostered the key artists of this style, including Jay Chou (Zhou Jielun 周杰倫) and Wang Leehom (Wang Lihong 王力宏). Jay Chou's Chineseness is considered "safe, compromising and non-confrontational" from the vantagepoint of the People's Republic of China (PRC) (Fung 2008: 79). The China Wind songs of both artists have been co-opted to reinforce the "one China" ideology, emphasising the same cultural roots of Taiwan and mainland China, evidenced by how CCTV spring galas have frequently staged performances of these songs as well as representing explicit or implicit moral messages (Liu, An, and Zhu 2015; Feng 2016). It has also been argued that the perception of Chineseness in China Wind pop music - regardless of the popularity of the style - leads to a sense of disconnectedness and ambivalence on the part of some listeners and viewers due to its audiences' different relationships to the concept of Chineseness (Lin and Um 2017; Lin 2019).

Following Chow's (1998) argument, Chineseness should be regarded as a theoretical question rather than a cultural fact, while there are certain challenges one faces when defining the notion of Chineseness in popular music. As Allen Chun (1996) points out, what it means to be "Chinese" for different groups has changed over history. Musicians referring to themselves as "the Chinese" or claiming to be producing Chinese popular music have also been made up of heterogeneous groups drawn from various nationalities and identities. The Sinophone concept as coined by Shih (2004) originally focused on literature and acted as a way of framing and theorising cultural production by Chinese-speaking populations in various parts of the world outside China while also enabling the theorisation of such production outside of PRC-centric conditions. However, Sinophone might not be applicable to the study of popular music in that contemporary popular music has been on the receiving end of many influences from cultural globalisation, particularly as music genres, production, and distribution are constantly crossing borders, whether these be national or cultural. In addition, Sinophone articulation's lingual-centric approach, although including various languages, is still defined by one's spoken languages. Lim argues that it also counts as a form of essentialism, which undermines cultural production and cultural identity when using a language that is not one's own (2011: 38), as is common in the production of popular music.

Chineseness in popular music therefore has to be understood in the context of global capitalism and the transnational flows of popular culture. The "strategic essentialism" (Zeng 2013: 93) deployed in Wang and Chou's respective work often presents and markets an artist image based on a PRC-inspired attempt to supersede Western cultural hegemony. Grounding itself in the complexities of the cultural industries' mechanisms and layers of identity signifiers, popular music is a distinct medium for the academic investigation of Chineseness. Hence, this article engages with the notion of Chineseness as not only a discursive construct (Ang 1998), but also as an aesthetic and sonic entity, one that conveys representations that signify 
forms of Chinese identity serving particular functions for specific audiences. The production of popular music can be viewed as a process of constructing "symbolic goods" (Jones 2012: 46) involving various companies and sectors. The production and consumption of popular music - differentiated from art or folk music - is made possible in an industrial monetary economy where it becomes a commodity (Tagg 1982: 2000). The understanding of this process opens up the opportunity to pursue questions regarding the functions of Chineseness.

After "China Wind," and even though there have been songs featuring stronger Chinese cultural signifiers released in the 2010s, such as Diana Wang's "Poem" (Yibu chengshi 一步成詩, released in 2017), and "Flow," released in 2016 by Khalil Fong (Fang Datong 方大同) and Wang Leehom, generally speaking, there have been fewer opportunities to group such songs into a given style for promotion or genre labelling, as well as a decreased fascination with China Wind's stylistic originality. In other words, China Wind, as a pop music trend displaying certain conventions reflecting or representing Chineseness, has declined. In a radio interview in 2018, David Tao (Tao Zhe 陶喆), a singer and producer of several China Wind hits, remarked that "we had a lot less China Wind songs in these past few years (...) maybe it is time to bring it back?"1 Tao's observation reflects how he perceived this musical style's decline.

Tagg's (2000) proposed model for analysing popular music is able to shed some light on the rise and fall of this music style, as it stresses looking at the "interests, needs, and aims" of both "emitters" and "receivers" of popular music, which is necessary for mass distribution to a large group of listeners, whereby it becomes a commodity in an industrial monetised economy (2000: 81). In this sense, the functions of perceived Chineseness in popular music have yet to be explored, as previous literature (Chow and De Kloet 2009; Chung 2011) tended to focus on the sense of Chinese pride clearly inscribed in its lyrics or the employment of the sound of traditional Chinese musical instruments. It is important to investigate that for the extramusical associations, where the production and consumption of Chineseness took place and how they may appear on the emerging platforms, as well as identifying different ways of representing Chinese culture's evolution.

This article examines two ways in which Chineseness is constructed in popular music that has been relevant after China Wind, respectively, a re-centred Chineseness in the creative industries and Chineseness as a globalising project. With a particular focus on two key artists who have been known for their contribution to China Wind music, namely Jay Chou and Wang Leehom, this article will adopt methods of textual analysis of music, performances, and media content, along with interviews with industry workers. It will start by providing an overview of existing debates and questions concerned with nationalisms, identities, and Chineseness in Chinese popular music. Then it will examine the internationally franchised televised music contest, The Voice of China (Zhongguo hao shengyin 中國好聲音), ${ }^{2}$ focusing on how the image of China was constructed and broadcasted transnationally, and Jay Chou's presence in the final episode of season four. Next, it will analyse the recent work of Jay Chou and Wang Leehom, along with their strategies to represent Chineseness in the international market, while projecting an international ethos to their local audiences.

\section{Chineseness, Chinese nationalisms and popular music}

How a particular Chinese identity is constructed and represented in popular music - particularly Mandopop, Cantopop, and Chinese rock - has been pursued academically by various scholars (Chua 2001; De Kloet 2005; Fung 2008; Chow and De Kloet 2013; De Kloet and Fung 2017; Lin 2019). Although the production of different cultural forms of Chineseness has been argued to be without a centre (Tu 1992; Chua 2001), it is also acknowledged that each region has had a different role to play in the production and consumption of Chineseness at different times (Chun 1996; Chua 2001; Ang 2013; Chun 2017). Nonetheless, Ang (2013) argues that an absolutist sign is being reinforced by the reductive logic of diaspora in an age of China's rise (2013: 20), meaning that the PRC's carefully constructed Chineseness has become more assertive while the diaspora are less able to contribute to the articulation of Chinese identity.

There have also been wider discussions regarding how popular, populist, or bottom-up nationalisms are manifested in Chinese popular culture. Populist nationalists tend to propagate an exaggerated version of history that often portrays imperial China as benevolent and superior to other cultures, while then using this history as a foundation for national pride (Yu 2014). Scholars argue that popular nationalism does not exist only as a counter-narrative to official nationalism, but occasionally serves the purpose of stabilising the state through the partial inclusion of the public (Li 2009; Hyun and Kim 2015; Yu 2015).

One recent example, the talent show The Rap of China (Zhongguo you xiha 中國有嘻哈), highlights how genres of pop music could be branded as national while triggering censorship and debate about localisation of this given genre. Since the show aired in 2017, Chinese hip-hop has been gaining widespread recognition while also being co-opted by the Chinese authorities (Amar 2018). In other words, the versions of Chineseness perceived in both the music and the show have been institutionalised and authorised via the state's interference. The relevant scholarship has highlighted political, economic, and cultural realities in relation to how Chineseness is shaped (Fung 2008; Baravovitch 2010; Chow and De Kloet 2011), but organisational practices connected to the production of music and cultural products, which reinforce or negate nationalistic discourses, are often neglected. By developing the analysis of The Voice of China alongside examining its production practices based on practitioner perspectives, the following discussion will illuminate the ways in which constructed Chineseness functions in popular music's transnational flows.

\section{Re-centred Chineseness in creative industries: The Voice of China}

Season four of The Voice of China was aired on Zhejiang TV (Zhejiang weishi 浙江衛視) in 2015 and gained immense popularity. This internationally franchised television singing competition attracted an average viewership of $4.8 \%$ of the PRC's total television audience, ${ }^{3}$ and it was reported that the televised final competition on 7 October 2015 was

1. “馬世芳/耳朵借我' 2018.01.29 深度專訪陶拮” (“Ma Shifang/Erduo jie wo" 2018.01.29 Shendu zhuanfang Tao Zhe, "Ma Shi-feng/Lend me your ears": In-depth interview with David Tao, 29 January 2018), https://www.youtube.com/watch?v=EJHp3YzGwhY (accessed on 27 February 2019).

2. The Voice of China aired from 2012-2016; in 2016, due to licensing issues, the name of the show changed to Sing! China (Zhongguo xin ge sheng 中國新歌聲), but the format of the show stayed largely the same.

3. “中國好聲音第四季落幕了, 7 個關鍵數字告訴你為什麼它仍然是國內最成功的綜㙯節目” (Zhongguo haoshengyin disiji luomu le, 7 ge guanjian shuzi gaosu ni weishenme ta rengran shi guonei zui chenggong de zongyi jiemu, As The Voice of China Season 4 draws to a close, seven key statistics show it is still the most successful entertainment TV show in China), Q Daily, 9 October 2015, http://www.qdaily.com/articles/15786.htm (accessed on 27 February 2019). 
watched live by 100 million people via online streaming platforms alone, while the television viewership for the episode was more than $6 \%$ of the PRC's television audience. The finale took place in the renowned Bird's Nest in Beijing, a national stadium with a capacity of 80,000. During this season, Jay Chou, the "Father of China Wind" (Cao 2006, as cited in Chow and De Kloet 2011), joined the show as a coach and encouraged many of his fans to watch the contest. He said to a finalist on his team, the Australian Chinese Li An: "Chinese music is the coolest. You should sing more China Wind (zhongguofeng)."

Alongside Jay Chou's emphasis on and praise of how cool Chineseness was, it is not difficult to notice that celebrating Chinese culture is the central theme of the show. The visual effects consist of Chinese calligraphy with dancers wearing cheongsam (qipao 旗袍) with red fans in hand and the sound of the erhu fiddle incorporated into an R\&B ballad, one of the most well-known of Jay Chou's China Wind songs, "Hair Like Snow" (Fa ru xue 髮如雪), released in 2005. On stage, the China Wind of the 2000s is rising again. However, the display of a re-centred Chineseness that points the diaspora back to the centre - namely the PRC - is now more explicit.

The success and popularity of the show created opportunities for emerging artists, not only for those from the PRC, but also for those from the Sinophone world. Hinry Lau is a singer-songwriter from Hong Kong who was known to his audience and followers primarily because he won the Hong Kong regional round of The Voice of China 2014 (season three); his music writing was influenced deeply by listening to Jay Chou's China Wind music as a teenager. The impact of his appearance on the show was tremendous, and Hinry Lau has claimed that this led to him being able to sustain his own studio in Ngau Tau Kok without having to take on other jobs. ${ }^{4}$

Regardless of the wider impact of the show, a common feature throughout all the seasons of The Voice of China is that its subtitles usually underline each contestant's respective Chineseness by highlighting their place of origin. Such labelling often creates tension between mainland China and Taiwan. The categorisation of "Chinese Taiwan" were often heavily criticised by netizens in Hong Kong or Taiwan for their PRC-centric implications. The tension could be underscored by a planned protest against the Sing! China concert in Taipei in 2017, which led to cancellation of the concert. This illustrated the resistance to a particular version of Chineseness and raised questions regarding whether the concert was propaganda that would have compromised Taiwan's sovereignty. These categories, along with the sound and images involved in singing "China's" praises in unity, lock individual contestants with diverse backgrounds into articulating a singular origin, namely China, a representation that is hegemonic in its ambition and intention. This is further evidenced in the short film broadcasted to the audience right before the start of the competition, when the narrator speaks with a passionate voice:

Wherever there is Chinese blood, there are footprints of The Voice of China. Even thousands of rivers and mountains cannot divide the continuity of Chinese culture (Zhonghua wenhua 中華文化); hundreds of words and songs cannot express how the blood and pulse of Huaxia (華夏) sons and daughters are deeply intertwined. (The Voice of China, season 4 finale)

Both Zhonghua and Huaxia evoke a cultural entity with a history longer than the contemporary Chinese nation-state, while the show also searched for Chinese musical talent not just in the PRC but also in places where the show identified as having "Chinese blood." The China Wind was still blowing as nationalist sentiments continued to be expressed throughout the competition. However, this was not just an extension or repetition of China Wind's previous popularity as we have seen in the 2000s. The representation and specification of a re-centred Chineseness have become even more assertive and explicit, in which concepts such as "roots" and "blood" are highly valued.

While Jay Chou's Chineseness in China Wind songs is argued to be intentionally ambiguous and vague (Chung 2011), a tactic that cleverly avoids potential dissimilarities in the perception of Chineseness in different markets, arguably, the presentation of Chineseness in The Voice of China is informed by the increased assertiveness of a mainland Chinese nationalism by calling out the regions and nations that a given contestant represents, and calling them back to the stage of the motherland. For those contestants from the diaspora and who seem peripheral to the construction of Chineseness as compared to the perceived centre, the performance of their ethnicity with a specifically manufactured diasporic mentality of "returning to the motherland" was demanded. After China Wind, Jay Chou has continued to actively engage with the public by representing some music styles and values, as evidenced in The Voice of China. A sense of panChineseness is constructed in the PRC-produced shows by including ethnic Chinese, thereby presenting a sense of a singular community. This redefines the meaning of being a Chinese singer and restructures the geopolitics of these artists' career development.

Jamie, ${ }^{5}$ one of the former directors of The Voice of China, shared his experience of being responsible for making the show's creative production decisions, as well as presenting its version of Chineseness. The show has three director teams, and each group has about 20 directors. Of the approximately 60 directors in total, each has to find and bring around 200 singers to the internal auditions. More than 10,000 singers will have a chance to perform in front of the director teams, but only a few of them will sing to the coaches, and even fewer will ever be broadcast. Jamie implied that even though the state owns a very limited share in most commercial channels, the higher executives have meetings with state officials to "listen to directions and advice" (tingqu zhidao yijian 聽取指導意見), and all lyrics are examined before they are approved. Jamie also described how, as directors, they often seek participants with whom prospective viewers can identify, then "socialise" the participants into their roles (Mast 2016):

\section{We wanted to find those singers with "feelings" (qinghuai 情懷) and characteristics.}

If there's an ethnic Chinese singer from overseas, we will indicate to him that you have black hair and yellow skin, but you have never come to this land. Now you are back to the land where your father or grandfather used to live, standing on the yellow soil facing a Chinese audience of 1.3 billion. What do you want to say? What do you want to sing? At this moment, he will not want to sing American or European pop songs. We give him some encouragement and a bit of a push, usually like what I just said. It will bring him to tears.

The boundaries and standards that directors and producers use to make decisions are informed by practices shaped by a capitalistic logic and the

\footnotetext{
4. Interview with Hinry Lau, conducted in Ngau Tau Kok, Hong Kong, 19 November 2015. All interviews were conducted in English and Mandarin, and translated by the author unless otherwise stated.
}

5. "Jamie" (pseudonym), personal interview in Hong Kong, 16 November 2015. 
attempt to avoid censorship. These practices become an asset, not just for profit-making, but also in terms of the active construction and projection of a Chineseness that is anticipated and will be shared by the target audience. Although the content and sense of nationalism staged on The Voice of China are moderately informed by officials, the dynamic between the programme, the audience, and the state is far more sophisticated than simply imposing a top-down official nationalism. This nationalism is commercial and manufactured, carefully regulated, and calculated in order to influence and construct audience perception of what is considered "real." Rather than simply catering to an official taste, commercialism, professionalism, and capitalist logic maximising ratings are all significant factors shaping the programme's narratives.

Fung (2016) argues that the state relies on global capital to convey a neo-nationalistic ideology to its population. Even though the PRC's creative industries have borrowed expertise and imported global content, ideological control was not lessened. In relation to The Voice of China, it is evident that whose Chineseness is authorised and how it is negotiated between different stakeholders are central to such presentations. On The Voice of China stage, China is imagined as a cultural and geographical community (Anderson 1983) bound together by blood. This deep connection is presented as unbreakable and unquestionable, transcending time, space, and other identity politics issues deemed to be of lesser importance. The clear display of Chineseness in the show serves to produce locality (Appadurai 1996) within a globalised mass-mediated culture. Although the musical elements employed in the performances share similarities with those of China Wind pop music, the emphasis on "blood" and "roots" presented on the stage conveys an even more assertive message to the periphery. This re-centred Chineseness does not only continue to present a state-framed ideology, but also seeks to convey a form of nationalism that co-opts the periphery.

The re-invention and re-appropriation of Chineseness is evident in The Voice of China, produced in the PRC, which has featured a strong calling out to the rest of the Chinese-speaking world to come back to Chinese culture through the search for their "roots" and by directing their talent back to the motherland. In season four, Jay Chou's presence and his high praise of China Wind music resonated with the style's popularity in the previous decade, while the presentation of Chineseness is even more assertive and compliant with a PRC-led nationalism, thereby re-centring Chineseness. Evident in interviews, the popularity of the show marks a new stage in the emergence of Sinophone transnational cultural economies in which the PRC's influence has grown significantly. Representations of Chinese national identity in these shows were generated by practices influenced by complex factors, including the markets, the pursuit of maximum profit, state-, self-, and corporatecensorship, and the producers' professional practices.

\section{Jay Chou and Wang Leehom's recent work as globalising projects}

As with many other trends in pop music, the popularity of China Wind benefited from its social, political, and economic settings during the 2000s. Two of the most renowned artists who have actively incorporated Chineseness into their popular music are Jay Chou and Wang Leehom. While the former was born and raised in Taiwan, the latter - whose parents were Taiwanese - was born and raised in New York. They are both singer-songwriters as well as producers, and they are known as multiinstrumentalists with versatile styles. Although both Chou and Wang were known for their ballads and R\&B-style singing, their music does not fall neatly into a particular genre, as is common for Mandopop albums to feature about ten songs, each of them influenced by different genres. Such a practice often leads people unfamiliar with Mandopop norms to find that the music fails to live up to the notion of a standard genre (Moskowitz 2010). This section will first reflect on the type of Chineseness represented in their work during the 2000s, which was considered the heyday of China Wind. Then, it will examine their more recent work, namely Wang Leehom's album Your Love (Ni de ai 你的愛, released in 2015) and Jay Chou's album Jay Chou's Bedtime Stories (Zhou Jielun de chuangbian gushi 周杰倫的床邊故事, released in 2016). It will also examine some of their singles to investigate how Chineseness - namely, the discursive, cultural, and aesthetic construct - has been shaped differently in terms of, respectively, music styles, how the music is labelled, and the strategies adopted to promote it.

As previously discussed, Chineseness is vaguely constructed in Jay Chou's China Wind songs, and there is little attempt to offer insights into Chinese modernity or the present state of China; rather, the focus is on an imagined past that is ancient and sophisticated. In China Wind's music videos, a nostalgic Chineseness is often romanticised, as evidenced in many of Jay Chou's songs - including "Hair Like Snow," "East Wind Breaks" (Dongfengpo 東風破, released in 2003), and "Chrysanthemum Terrace" (Juhua tai 㐘花 台, released in 2006). The intention to create a sound that is distinctively Chinese was verified in an interview with Jay Chou's manager and cofounder of his label, JVR Music, JR Yang, ${ }^{6}$ who described China Wind music as a new hybrid genre that has emerged from this competition:

Actually, the contemporary popular music, all of it is Western stuff. Why are there guitars in Chinese music? Drum sets? Bass? (...) Chinese music used to be composed in gong 宮, shang 商, jue 角, zhi 徵 and yu 羽, the five-tone scale, so what we do now is Western music. (...) If we use an agricultural product as our metaphor, zhongguofeng music might be a new species of vegetable. Foreigners (laowai 老外) may not know them; some of these vegetables are unfamiliar to their own tastes. But for us it is something to be proud of.

While "Hua" represents a vaguely constructed community that broadly includes ethnic Chinese across national borders, those "Others" who do not belong to this in-group are mainly foreign nationals. Laowai can be translated as "old outsider" and is a slang term for "foreigner" in Mandarin Chinese. Here, "laowai" are perceived as authenticating the value of popular music. This conceptualisation does not only have an impact on the industrial sector producing and promoting music; sometimes it manifests itself more directly, namely in the music itself or in artists' speech. Along with this rhetoric and the popularity of China Wind music, laowai, Chinese culture, or the Hua community's Other can be both subverted and competed with.

Wang Leehom's strategies and positioning are different. Wang locates himself through his lyrics by disclosing his own story as a second-generation Asian immigrant in New York in "Descendants of the Dragon" (Long de chuanren 龍的傳人) - a cover of a folk song. The original version was written by Hou Dejian 侯德健, sung by Li Jianfu 李建復, and first released in 1978. The song was written reflecting the historical event when the USA terminated its diplomatic relations with the Republic of China (ROC - Taiwan) and switched its diplomatic recognition to the PRC. The lyrics reflect a sense of Chinese nationalism, which declares the authenticity of ROC Chineseness.

6. JR Yang (愓峻榮 Yang Junrong), interview in JVR Music, Taipei, Taiwan, 22 January 2016. 
In his version, Wang added a rap element in English and adapted some lyrics focusing on his second-generation immigrant story. Starting from his cover of "Descendants of the Dragon," Wang has gradually started to embrace "Chinked-out" as a genre in his later work, including "Heroes of the Earth" (Gaishi yingxiong 蓋世英雄) and "Viva Huaren" (Huaren wansui 華人萬歲), where his goal was to "let the Chinese [Huaren] be heard."

In his own words, his motivation is to be "an ambassador for Chinese culture," an ambition he has clearly defined. His music calls for a new sense of Chinese cultural nationalism and occasional criticisms of US racism. He has actively incorporated Chinese music instruments in his pop songs and created a style that he labelled "Chinked-out" in 2005. Wang possesses an outsider status, namely as an Asian-American who has returned to Chinese culture with a diasporic mentality. His efforts to incorporate Chineseness have a clear goal, which is to reverse the negative connotations of "Chink" while "creating a sound that is both international and Chinese" (Wang 2012: 11). These personal and ideological motivations are evident in many of his songs, such as "Open Fire" (Huoli quankai 火力全開, released 2011), in which he wrote and sang the second verse in English:

$$
\begin{aligned}
& \text { So many accusations of an Asian invasion } \\
& \text { Here they come a pointin' fingers at me (...) } \\
& \text { Gonna stop this negativity turn it into positivity with integrity } \\
& \text { Giving all of me for all to see this fight for equality } \\
& \text { But even if they blame us, try to frame us nobody can shame us } \\
& \text { I'm a sing this next verse in Chinese. }
\end{aligned}
$$

As discussed earlier in this article, it is noticeable that China Wind music has been transforming and evolving into something different. Chou and Wang's pursuit of musical styles other than China Wind are evident on their recent albums, including Your Love (2015) and Jay Chou's Bedtime Stories (2016). There is no particular emphasis on musical or lyrical Chineseness in Your Love. Other than Mandarin ballads, this album includes songs with an apparent EDM (electronic dance music) influence as evidenced by Wang's collaboration with Swedish DJ Avicii on the song "Losing Myself" (Wangwo 忘我). On Jay Chou's Bedtime Stories (2016), there is also no identifiably China Wind pop song as found on most of his previous albums. In other words, the continuity in Chou's production of China Wind songs on every album from 2000 to 2014 paused in 2016. In an interview with JVR Music's CEO, ${ }^{8}$ when asked if the company would produce more China Wind songs as Jay Chou previously encouraged the contestants of The Voice of China to do, JR Yang said that he looked forward to the further growth and development of this style as advanced by emerging artists, but it might be difficult to go beyond what Jay Chou and the lyricist Fang Wenshan 方文山 had already achieved, as this was an exceptional success that required the right artists working together at the right time.

It is noteworthy that on Jay Chou's Bedtime Stories, there is only one song that still features a riff in a major pentatonic scale, "Now You See Me." This is an electronic hip-hop song written for the American film Now You See Me 2, in which Jay Chou played a small role and wrote the theme song. On the film's official YouTube channel, it was described as the first time a Chineselanguage song was a theme tune in a Hollywood film. However, other than some riffs that still have an identifiable influence from the Chinese fivetone musical system, "Now You See Me" features various styles and musical cultures, such as the set of musical notes employed in the bridge, reflecting Hollywood's imagining of an exotic Orient. The pieces of the collage are no longer confined to recollections of ancient China or the re-imagining of traditional Chinese culture; instead, they can function as performances of a global Chineseness and Asianness that are attempting to connect to an international market.

Several of Jay Chou's China Wind songs in the 2000s became the theme tunes of Chinese films, all of which are set in imperial China. These songs include "Fearless" (Huo yuan jia 霍元甲), "Chrysanthemum Terrace" (Juhua tai 㐘花台), and "Golden Armor" (Huangjin jia 黄金甲). In contrast with the songs mentioned above, the performance of Chineseness in "Now You See Me," is not as explicit, but rather typifies a stereotyped, exotic Asianness. Nevertheless, in the written introduction and press release regarding this song, a "Huaren" (華人) artist trying to connect to a global audience was heavily emphasised, as if it this were a milestone to be proud of.Wang's album A.I. Love (2017) explores several themes and issues around artificial intelligence and its impact on human beings. Out of these eleven songs, there are three with more explicit references to Chinese culture and music. The song "Bridge of Fate" (Yuanfen yidaoqiao 緣分一道橋) is the theme song for the US-China coproduction blockbuster film The Great Wall (2016), directed by Zhang Yimou 張㙯謀 and starring Matt Damon. In this song, a 4/4 strumming pattern on the acoustic guitar along with electronic drumbeats function as the primary rhythmic foundation, while other instruments such as the bass, erhu, dizi, electric guitars, and pipa join gradually to build up and enrich the orchestration. It also features the female singer Tan Wei-wei 譚維維, while both her and Wang's vocal performances emphasise their raspy and husky voices, recalling traditional Chinese operatic singing skills, such as sliding tone (Everett and Lau 2004) and falsetto voices. The first verse is taken from a Tang poem by Wang Changling 王昌齡, titled "Marching Out to the Frontier," (Chu Sai 出塞) which depicts a battlefield scene. The rest of the lyrics are by Fang Wenshan, the lyricist who wrote the lyrics for most of Jay Chou's China Wind songs. Another song on this album that seeks to present a Chinese atmosphere is "Hearing Love" (Ting ai 聽愛), a ballad featuring the erhu and guzheng. It is also the theme song of the film Tofu (Doufu zhuan 豆福傳, 2017, 85 min.), with the lyrics also composed by Fang Wenshan. Wang's latest China Wind music strongly reflected the China Wind aesthetics of the 2000s with the songs appearing to be serving a specific purpose, namely fitting the theme of the film. In this sense, Wang's latest China Wind songs have a functional role to play, strongly reflecting ties to the film industry.

While surging nationalism is a communal reaction to the impact of globalisation, the Chinese popular music market "does not possess the will or capability to resist authoritarianism; rather, it perpetuates and propels the self-feeding cycle of interpellation by Chinese nationalism" (Gao 2015: 484). The music of both Chou and Wang reflects this negotiation between the global and the local, as well as underlining a rising nationalism. Other than representing Chinese culture in their music, both artists are pursuing a global relevance, as well as representing singers belonging to or originating in the Chinese-speaking world, who also have a global presence. However, the consumers of this globalising image may not necessarily be a Western audience, but rather the younger Chinese generation who seek "a sense of glamour, fantasy, and modernity" in popular culture (Fung 2016: 3016). At the same time, the cultural products have also been consumed by Chinesespeaking populations who are transnational subjects residing overseas, and for whom music provides the point of reference to one's roots and cultures (Lin 2019).

7. See https://www.youtube.com/watch?v=p6UDLOXwbNk (accessed on 27 February 2019).

8. JR Yang, interview conducted at JVR Music, Taipei, Taiwan, 22 January 2016. 
This strategy - namely, to project Chineseness as a globalising project - is best exemplified by Jay Chou's appearance on the Nasdaq screen at Time Square in January 2019. He was voted the most influential Chinese singer on Kugou 酷狗, the Chinese streaming service owned by Tencent (Tengxun 騰訊). However, other than his name, the text shown on the Nasdaq screen alongside a photo of Chou is all in Chinese. Such a projection of a globalising Chineseness caters to the hopes of the well-educated and well-travelled Chinese newly rising classes. They not only aspire to take part in global culture or to be "compatible with the global world" (Fung 2016: 3016), but also embrace the nation-branding of the PRC as a rising and thriving globalised state. While Chinese films with an ancient setting still seek out China Wind songs to borrow their sound and embellish their narrative, seeking global visibility and participation - as Jay Chou and Wang Leehom have done - may be a strategy adopted to construct a pop music Chineseness in the next decade.

The analysis of the latest work by Jay Chou and Wang Leehom exemplifies the creative and commercial strategies employed to tackle Chineseness in the form of participating and collaborating with the global market. The projection of this international visibility has gradually moved away from the conventions of China Wind music, which created a style that sounded modern, trendy, and Chinese at the same time. The artists' latest oeuvre reflects the desires of the new rising classes in China, who aspire to be integrated into globalised modernity while simultaneously competing with the rest of the world. Nevertheless, China Wind songs retained pragmatic values, particularly in some Chinese films set in ancient China. In the case of The Great Wall, it was a fictional past. "Bridge of Fate," a China Wind song, with its music and use of traditional instruments recalls ancient Chinese culture and philosophy. As is the case with most China Wind songs, it projects a vague historical and romanticised Chineseness that enhances its storytelling. In this sense, China Wind music functions similarly to the way music helps propel a film's narrative, and it was indeed composed for a film. Also, it is worth observing whether, in the hands of younger artists, China Wind songs will continue to project Chineseness in this particular form.

\section{Conclusion}

China Wind music, regulated by conventions and accepted by communities (Fabbri 2012), has had its meanings and popularisation documented in the media (Lan 2007) and studied by scholars (Fung 2008; Chow and De Kloet 2013; De Kloet and Fung 2017), while its audiences and communities have been investigated (Lin and Um 2017; Lin 2019). However, new ways of presenting Chineseness in popular music are currently evolving, corresponding to changes both in the global market as well as in local contexts.

This article discussed examples that illustrate the different ways in which musical Chineseness is constructed in transnational flows of culture, migration, and capital. These discussions have included evidence of a recentered Chineseness as presented on the stage of The Voice of China while examining the way in which two artists have constructed and utilised Chineseness in order to sustain creative and globalising projects. Markets, industrial practices, media censorship, state policy, cross-industry convergence, and musicians' artistry will all continue to play a part in the construction and dissemination of Chineseness in popular music. As Fiske (1989) puts it, "all popular culture is a process of struggle over the meanings of social experience" (1989: 29). This article has adopted an ethnographic approach to its production, which has shed some light on how a particular version of Chineseness has been shaped while the functions of perceived Chineseness have been explored in this same context. While nationalistic sentiments in a variety of forms have emerged both in China ${ }^{9}$ and internationally, there should be no reason to halt the exploration of the specificities of these discursive and aesthetic constructs, as well as investigating their social and political implications in popular music. China Wind pop music may be a fad that comes, goes, and transforms into something else quickly, but as is evident in the cases presented in this article, Chineseness in popular music also has an afterlife. Questions of Chineseness should be continuously investigated in the evolving cultural practices of popular music in the Sinophone world, as they are always intertwined with questions of power, cultural representation, and politics.

\section{Dr. Chen-Yu Lin is Research Fellow at the Institute of Popular Music (IPM), Department of Music, University of Liverpool, and Assistant Professor at Department of International Business, National Taiwan University. Her research interests include Mandarin popular music and music censorship. She is also a documentary producer who actively incorporates filmmaking and screening as research methods. Her films have been shortlisted for AHRC Research in Film Awards twice. No.1, Sec. 4, Roosevelt Rd., Taipei City 106, Taiwan (R.O.C.) (cylin@liv.ac.uk).}

\section{Manuscript received on 8April 2019. Accepted on 30 March 2020.}

9. See also: Yiwen Wang, "Homoeroticising Archaic Wind Music: A Rhizomatic Return to Ancient China" in this issue. 


\section{Primary Sources}

CHOU, Jay 周杰倫. 2003. “東風破” (Dong feng po, East Wind Breaks). Track 5 on 葉惠美 (Yeh Huei-mei). Alfa Music (Japan) [Compact Disc].

CHOU, Jay 周杰倫. 2005. "髮如雪” (Fa ru xue, Hair Like Snow). Track 3 on $十$ 一月的蕭邦 (Shiyiyue de Xiaobang, November's Chopin). Alfa Music (Japan) [Compact Disc].

CHOU, Jay 周杰倫. 2006. “菊花台” (Juhua tai, Chrysanthemum Terrace). Track 10 on 依然範特西 (Yiran fantexi, Still Fantasy). Alfa Music (Japan) [Compact Disc].

CHOU, Jay 周杰倫. 2006. "霍元甲” (Huo yuan jia, Fearless). Track 1 on 霍元甲 (Huo yuan jia, Fearless). Alfa Music (Japan) [Compact Disc].

CHOU, Jay 周杰倫. 2006. “黃金甲” (Huangjin jia, Golden Armor). Track 1 on 黄金甲 (Huangjin jia, Golden Armor). Alfa Music (Japan) [Compact Disc].

CHOU, Jay 周杰倫. 2016. Now You See Me. Track 9 on 周杰倫的床邊 故事 (Zhou Jielun de chuangbian gushi, Jay Chou's Bedtime Stories). JVR Music (Taiwan) [Compact Disc].

FONG, Khalil 方大同, and WANG Leehom 王力宏. 2016. Flow. Track 2 on 西遊記 (Xiyouji, Journey to the West). FUMUSIC (Hong Kong) [Compact Disc].

LI, Jianfu 李建復. 1980. “龍的傳人” (Long de chuanren, Descendants of the Dragon). Track 1 on 龍的傳人 (Long de chuanren, Descendants of the Dragon). Synco Cultural Corporation (Taiwan) [Cassette Tape].
WANG, Diana 王詩安. 2017. “一步成詩” (Yibu chengshi, Poem). Track 1 on 一步成詩 (Yibu chengshi, Poem). FUMUSIC (Hong Kong) [Compact Disc].

WANG, Leehom 王力宏. 2000. “龍的傳人” (Long de chuanren, Descendants of the Dragon). Track 1 on 永遠的第一天 (Yongyuan de diyitian, Forever's First Day). Sony Music (U.S.A.) [Compact Disc].

WANG, Leehom 王力宏. 2007. “華人萬歲” (Huaren wansui, Viva Huaren). Track 11 on 改變自己 (Gaibian ziji, Change Myself). Sony Music (U.S.A.) [Compact Disc].

WANG, Leehom 王力宏. 2011. “火力全開” (Huoli quankai, Open Fire). Track 1 on 火力全開” (Huoli quankai, Open Fire). Sony Music (U.S.A.) [Compact Disc].

WANG, Leehom 王力宏. 2017. “緣分一道橋” (Yuanfen yidaoqiao, Bridge of Fate). Track 9 on A.I. Love. Linfair Records (Taiwan) [Compact Disc].

WANG, Leehom 王力宏. 2017. “聽愛” (Ting ai, Hearing Love). Track 10 on A.I. Love. Linfair Records (Taiwan) [Compact Disc].

WANG, Leehom 王力宏, and Avicii. 2015. “忘我” (Wangwo, Losing Myself). Track 4 on 你的愛 (Ni de ai, Your Love). Homeboy Music (U.K.) [Compact Disc].

WANG, Leehom 王力宏, MC Jin, and Lee Yan. 2005. “蓋世英雄” (Gaishi yingxiong, Hero of the Earth), Track 3 on 蓋世英雄 (Gaishi yingxiong, Hero of the Earth). Sony Music (U.S.A.) [Compact Disc].

\section{References}

AMAR, Nathanel. 2018. ''Do You Freestyle?' The Roots of Censorship in Chinese Hip-Hop." China Perspectives 1-2(113): 107-14.

ANDERSON, Benedict. 1983. Imagined Communities: Reflections on the Origin and Spread of Nationalism. London:Verso.

ANG, len. 1998. "Can One Say No to Chineseness? Pushing the Limits of the Diasporic Paradigm." boundary 2 25(3): 223-42.

ANG, len. 2013. "No Longer Chinese? Residual Chineseness after the Rise of China." In Julia Kuehn, Kam Louie, and David Pomfret (eds.), Diasporic Chineseness after the Rise of China. Vancouver and Toronto: UBC Press. 17-31.

APPADURAl, Arjun. 1996. Modernity at Large: Cultural Dimensions of Globalization. Minneapolis and London: University of Minnesota Press.

CHOW, Rey. 1998. "Introduction: On Chineseness as a Theoretical Problem." boundary 2 25(3): 1-24.

CHOW, Yiu-fai, and Jeroen DE KLOET. 2011. "Blowing in the China Wind: Engagements with Chineseness in Hong Kong's Zhongguofeng music videos." Visual Anthropology 24: 59-76.
CHOW, Yiu-fai, and Jeroen DE KLOET. 2013. Sonic Multiplicities: Hong Kong Pop and the Global Circulation of Sound and Image. Chicago: Intellect.

CHOW, Yiu-fai. 2009. "Me and the Dragon: A Lyrical Engagement with the Politics of Chineseness." Inter-Asia Cultural Studies 10(4): 544-64.

CHUA, Beng Huat. 2001. "Pop Culture China." Singapore Journal of Tropical Geography 22(2): 113-21.

CHUN, Allen. 1996. "Fuck Chineseness: On the Ambiguities of Ethnicity as Culture as Identity." boundary 2 23(2): 111-38.

CHUN, Allen. 2017. Forget Chineseness: On the Geopolitics of Cultural Identification. Albany: State University of New York Press.

CHUNG, Yong. 2011. Hearing Chinoiserie: The Discourse Analysis of Chinese Pop Music during 2000-2010. Master thesis. Taiwan, National Chengchi University.

DE KLOET, Jeroen. 2005. "Authenticating Geographies and Temporalities: Representations of Chinese Rock in China." Visual Anthropology 18(2-3): 229-55.

DE KLOET, Jeroen, and Anthony FUNG. 2017. Youth Cultures in China. Cambridge: Polity. 
DE KLOET, Jeroen. 2010. China with a Cut: Globalisation, Urban Youth and Popular Music. Amsterdam: Amsterdam University Press.

DENORA, Tia. 1999. "Music as a Technology of the Self." Poetics 27(1): 31-56.

DENORA, Tia. 2000. Music in Everyday Life. Cambridge: Cambridge University Press.

EVERETT, Yayoi Uno, and Frederick LAU (eds.). 2004. Locating East Asia in Western Art Music. Middletown, CT:Wesleyan University Press.

FABBRI, Franco. 2012. "How Genres are Born, Change, Die: Conventions, Communities and Diachronic Process." In Stan Hawkins (ed.), Critical Musicological Reflections: Essays in Honour of Derek B. Scott. Surrey: Ashgate. 179-91.

FENG, Dezheng. 2016. "Promoting Moral Values Through Entertainment: A Social Semiotic Analysis of the Spring Festival Gala on China Central Television." Critical Arts 30(1): 87-101.

FISKE, John. 1989. Understanding Popular Culture. New York: Routledge.

FRITH, Simon. 1996. "Music and Identity." In Simon Hall and Paul du Gay (eds.), Questions of Cultural Identity. Copenhagen: Copenhagen Business School. 108-27.

FRITH, Simon, and Angela MCROBBIE. 1990. "Rock and Sexuality." In Simon Frith and Andrew Goodwin (eds.), On Record: Rock, Pop and the Written World. London: Routledge. 371-89.

FUNG, Anthony. 2007. "The Emerging (National) Popular Music Culture in China." Inter-Asia Cultural Studies 8(3): 425-37.

FUNG, Anthony. 2008. "Western Style, Chinese Pop: Jay Chou's Rap and hip-hop in China." Asian Music 39(1):69-80.

FUNG, Anthony. 2016. "Strategizing for Creative Industries in China: Contradictions and Tension in Nation Branding." International Journal of Communication 10(4001): 3004-21.

GAO, Zihong. 2015. "When Nationalism Goes to the Market:The Case of Chinese Patriotic Songs." Journal of Macromarketing 35(4): 473-88.

GILROY, Paul. 1993. The Black Atlantic: Modernity and Double Consciousness. Cambridge: Harvard University Press.

HYUN, Ki Deuk, and Jinhee KIM. 2015. "The Role of New Media in Sustaining the Status Quo: Online Political Expression, Nationalism, and System Support in China." Information Communication and Society 18(7): 766-81.

JONES, Michael. 2012. The Music Industries: From Conception to Consumption. London and New York: Palgrave Macmillan.

LAN, Hui. 2007. “中國風驚艷台灣南洋流行曲中國元素崛起” (Zhongguofeng jingyan Taiwan Nanyang liuxingqu Zhongguo yuansu jueqi, China Wind sweeps through Taiwan and Nanyang: The rise of Chinese elements). 藍慧 Asiaweek, 22 July.

LI, Mingshen. 2009. "Chinese Nationalism in an Unequal Cyber War." China Media Research 5(4): 63-79.
LIM, Song Hwee. 2011. "Six Chinese Cinemas in Search of a Historiography." In Song Hwee Lim and Julian Ward (eds.), The Chinese Cinema Book. London: Palgrave Macmillan. 35-44.

LIN, Chen-yu. 2019. "Multidimensionality of Chineseness in Taiwan's Mandopop: Jay Chou's China Wind Pop and the Transnational Audience." In Eva Tsai, Tung-Hung Ho, and Miaoju Jian (eds.), Made in Taiwan: Studies in Popular Music. New York and London: Routledge. 189-99.

LIN, Chen-yu, and Haekyung UM. 2017. "From 'Blue and White Porcelain' to 'Island's Sunrise': Young Audience Perceptions of Chineseness and Taiwaneseness in Taiwan's Popular Music." East Asian Journal of Popular Culture 3(2): 153-67.

LIU, Chen, Ning AN, and Hong ZHU. 2015. "A Geopolitical Analysis of Popular Songs in the CCTV Spring Festival Gala, 1983-2013." Geopolitics 20(3): 606-25.

MCCLARY, Susan. 1991. Feminine Endings: Music, Gender, and Sexuality. Minneapolis: University of Minnesota Press.

NYE, Joseph. 1990. Bound to Lead: The Changing Nature of American Power. New York: Basic Books.

SHIH, Shu-Mei. 2004. "Global Literature and the Technologies of Recognition." PMLA 119(1): 16-30.

STOKES, Martin. 1994. "Introduction: Ethnicity, Identity and Music." In Martin Stokes (ed.), Ethnicity, Identity and Music: The Musical Construction of Place. Oxford and New York: Berg Publishers. 1-27.

SU, Zheng. 2010. Claiming Diaspora: Music, Transnationalism, and Cultural Politics in Asian/Chinese America. New York: Oxford University Press.

TAGG, Philip. 1982. "Analysing Popular Music: Theory, Method and Practice." Popular Music 2: 37-65.

TAGG, Philip. 2000. "Analysing Popular Music: Theory, Method, and Practice." In Richard Middleton (ed.), Reading Pop: Approaches to Textual Analysis in Popular Music. Oxford and New York: Oxford University Press. 71-103.

TU, Wei-ming. 1991. "Cultural China: The Peripheries as the Center." Daedalus: 1-31.

WALSER, Robert. 1993. Running with the Devil: Power, Gender, and Madness in Heavy Metal Music. Hanover, NH:Woodall.

WANG, Danping, and Bob ADAMSON. 2014. "War and Peace: Perceptions of Confucius Institutes in China and USA." Asia-Pacific Education Researcher 24(1): 225-34.

WANG, Grace. 2012. "The ABCs of Chinese Pop: Wang Leehom and the Marketing of a Global Chinese Celebrity." Journal of Transnational American Studies 4(1): 21.

WANG, Jian (ed.). 2011. Soft Power in China: Public Diplomacy through Communication. New York: Palgrave Macmillan.

YU, Haiyang. 2014. "Glorious Memories of Imperial China and the Rise of Chinese Populist Nationalism." Journal of Contemporary China 23(90): 1174-87. 